Marquette University

e-Publications@Marquette

College of Communication Faculty Research and

Publications

Communication, College of

4-1-2015

\title{
Toward an Ethical Model of Effective Crisis Communication
}

Young Kim

Marquette University, young.kim@marquette.edu

Accepted version. Business and Society Review, Vol. 120, No. 1 (Spring 2015): 57-81. DOI. (C) 2015

John Wiley \& Sons, Inc. Used with permission.

Young Kim was affiliated with Louisiana State University at the time of publication. 
Marquette University

e-Publications@Marquette

\section{College of Communication Faculty Research and Publications/Department of Communication}

This paper is NOT THE PUBLISHED VERSION; but the author's final, peer-reviewed manuscript. The published version may be accessed by following the link in the citation below.

Business and Society Review, Vol. 120, No. 1 (2015): 57-81. DOI. This article is (C Wiley and permission has been granted for this version to appear in e-Publications@Marquette. Wiley does not grant permission for this article to be further copied/distributed or hosted elsewhere without the express permission from Wiley.

\section{Toward an Ethical Model of Effective Crisis Communication}

Young Kim

College of Communication, Marquette University, Milwaukee WI

\section{Abstract}

The goal of this study was to develop and demonstrate a new ethical model for crisis communication. This article examined the crisis communication practices as well as literature and found essential elements-what, how, and when-for ethical and effective crisis communication. Based on these three variables, a new three-part model, the TTR Test, was proposed, utilizing three principles: Transparency (what), Two-way symmetrical communication (how), and Right time (when). To investigate how the test can be applied to the real world, this article examined BP's crisis communication during the 2010 Gulf of Mexico oil spill.

\section{Introduction}

In public relations practices, ethics has been regarded as a critical issue (Ki et al. 2012). Public relations professionals are aware of the importance of ethics and have created and maintained a code of ethics 
to guide organizations toward ethical practices (Fisher 2005; Ki et al. 2012). Despite these efforts, organizations frequently must deal with crises caused by unethical public relations practices. Recent examples include scandals in American financial organizations (e.g., Enron, WorldCom), as well as crisis in foreign companies operating in America (e.g., Toyota), which have showed the importance of ethics in crisis communication (Gower 2006; Piotrowski and Guyette 2010).

In the early 2000s, Enron and WorldCom faced similar crises as a result of unethical financial practices; however, each company's crisis communication affected its reputation in quite different ways. Ultimately, Enron's reputation was damaged more than WorldCom's (Wright 2006). The Toyota recall crisis also demonstrated the importance of ethics when dealing with a crisis (Piotrowski and Guyette 2010). Between 2009 and 2010, Toyota Motor Corporation, the world's largest car maker, faced the most challenging crisis in its history when allegations arose that sudden unintended acceleration could bring about a fatal accident (Kell 2011; Liker 2011). As it turned out, there was no evidence related to electronic problems in Toyota vehicles, yet the unethical crisis communication used during the incident damaged the company's reputation in the eyes of the American press and the public (Piotrowski and Guyette 2010).

Ethics is essential in crisis communication and must be taken into consideration in all public relations practices. Research about crisis communication ethics has been paid relatively little attention compared with other areas of communication or public relations. Surprisingly, not one study dealing with the ethics of crisis communication appears in the totality of published studies from 1991 to 2009 (An and Cheng 2007; Avery et al. 2010; Gower 2006; Seeger and Ulmer 2001). This gap between crisis communication and the importance of ethics was the impetus for this study.

This article examines literature related to crisis communication, including theories, models, and strategies, and establishes ethical principles in terms of what, how, and when essential elements must be employed for effective and ethical crisis communication. The resultant test of Transparency, Twoway communication, and Right time (TTR) is then applied to determine the ethics of BP's crisis communication during the 2010 oil spill crisis.

\section{Literature Review}

\section{Ethics and Public Relations}

From a philosophical and scholarly perspective, ethics may be defined as the study of what is right or wrong, fair or unfair, just or unjust; in a word, morality (Palenchar and Heath 2006). Within the field of public relations, ethics tends to involve the importance of communication. Heath and Ryan (1989) suggest that public relations' ethical role is based upon responsible, professional, and strategic communication management. Grunig and White (1992) note that public relations should be grounded in a worldview that incorporates ethics into the process of public relations. Grunig and Grunig (1996) directly link the ethics of public relations practitioners to communication, arguing that one should consider the impact of communication behaviors on stakeholders, yet follow deontological rules to be honest, truthful, and sincere when communicating (Grunig and Grunig 1996; Huang 2004). Researchers note that when communicating with stakeholders and publics to help an organization, public relations practitioners must discern how to communicate truthfully and refrain from doing harm (Bowen 2005; Fitzpatrick 2006). Palenchar and Heath (2006) reinforced the importance of ethics in public relations practices by arguing that "public relations practitioners can essentially incorporate ethics as an 
element of the brand management of organizations: good organizations working and communicating well" (p. 137).

Grunig and Hunt's (1984) two-way symmetrical model, which emphasizes the exchange of information based on balanced communication between the organization and the public, has received a great deal of attention, particularly in regard to its focus on the relationship to ethical communication (Huang 2004; Palenchar and Heath 2006). Despite existing arguments that symmetrical communication and ethical communication are two different conceptual dimensions, public relations literature postulates that two-way symmetrical communication is inherently ethical (Grunig 2001; Grunig and Grunig 1992; Grunig and White 1992; Huang 2004). Grunig and Hunt (1984) developed a two-way symmetrical communication model to show that the concept is inherently ethical: "telling the truth," "interpreting the client and public to one another," and "management understanding the viewpoints of employees and neighbors as well as employees and neighbors understanding the viewpoints of management" (Grunig and White 1992, p. 289). More recently, Huang (2004) demonstrated this notion through three surveys of Taiwan's Top 500 companies and public relations agencies. She indicated that two-way symmetrical communication is an essential element for ethical crisis communication in public relations practice (Huang 2004).

The fact that several ethical decision-making models and practical models of public relations ethics include two-way symmetrical communication indicates its ethical nature (Place 2010). Bowen (2004) includes symmetrical communication as one of six ethical considerations in her normative model of ethical management and communication. Hon (2006) also highlights the importance of symmetrical communication through a four-step ethical model for responsible advocacy with activist publics. Fitzpatrick and Gauthier (2001) proposed principles of responsible advocacy in public relations based on two-way symmetrical model and other theoretical bases for public relations ethics.

Although some researchers have made efforts to emphasize the importance of ethics in the realm of both practices and academics of public relations, ethics has not been enthusiastically and specifically reviewed, especially in the field of crisis communication (Seeger 2006; Wright 2006).

\section{Crisis and Crisis Communication}

While there is no standard definition of crisis, a few characteristics consistently emerge: significant threat(s), unpredictability, and urgency (Coombs 1999, 2007; Falkheimer and Heide 2006). Barton $(\underline{1993}$, p. 2) defined crisis as "a major unpredictable event that has potentially negative results. The event and its aftermath may significantly damage an organization and its employees, products, services, financial condition, and reputation." Similarly, Fearn-Banks $(\underline{1996}$, p. 1) considered a crisis "a major unpredictable event that has potentially negative outcome affecting an organization, company, or industry, as well as its publics, products, services, or good name." Coombs $(\underline{1999}, \underline{2007})$ more clearly addressed the similar characters by defining crisis as "an event that is an unpredictable, major threat that can have a negative effect on the organization, industry, or stakeholders if handled improperly" (1999, p. 2). More recently, he fleshed out this definition, "a crisis is a sudden and unexpected event that threatens to disrupt an organization's operations and poses both a financial and reputational threat" (2007, p. 164). He further classified by adding to the crisis definition, "the perception of an unpredictable event that threatens important expectancies of stakeholders and can seriously impact an organization's performance and generate negative outcomes" (2010, p. 19). In public relations 
practice, the Institute for Crisis Management, a research-based crisis management consulting firm in the United States, defines a crisis as "a significant business disruption that stimulates extensive news media coverage. The resulting public scrutiny will affect the organization's normal operations and also could have a political, legal, financial, and governmental impact on its business" (Gower 2006).

In sum, crises are unusual occurrences that cannot be predicted but are expected and entail significant threats (Coombs 2010; Gower 2006). Seeger (2006) divided crisis into three basic categories: "natural disasters" (e.g., tsunamis, earthquakes, and wild fires), "industrial accidents" (e.g., spills, explosions, and product defects), and "intentional events" (e.g., workplace violence, product tampering, and terrorist attacks). According to Coombs (1999), crises can be clustered into identifiable types: natural disasters, malevolence, technical breakdowns, human breakdowns, challenges, megadamage, organizational misdeeds, workplace violence, and rumors.

Crisis communication is the crisis response, what organizations say and do after a crisis, on the crisis types (Coombs 2010). More specifically, crisis communication in public relations is an activity-the actual words (verbal) and actions (nonverbal) - the organization uses to reduce and contain harm caused by significant threats, unpredictability, and urgency (Coombs 1999; Reynolds and Seeger 2005; Seeger 2006). In other words, crisis communication can be defined as "the collection, processing, and dissemination of information required to address a crisis situation" (Coombs 2010, p. 20). This involves the sending and receiving of messages "to prevent or lessen the negative outcomes of a crisis and thereby protect the organization, stakeholders, and/or industry from damage" (Coombs 1999, p. 4). Crisis communication is also "verbal, visual, and/or written interaction between the organization and its stakeholders (often through the media) prior to, during and after a negative occurrence" (FearnBanks 2002, p. 480). Such crisis communication seeks to explain the specific event, identify likely consequences and outcomes, and provide specific harm-reducing information to affected communities. In crisis communication, an honest, candid, prompt, accurate, and complete manner is required (Reynolds and Seeger 2005; Seeger et al. 1998).

\section{Ethics in Crisis Communication Research}

Communication scholars have paid much attention to crisis communication and its evolution in recent years (An and Cheng 2007). Falkheimer and Heide (2006) argue that crisis communication has mainly focused on the production of information, such as designing material in preparation for crisis, to cope with an existing crisis, or to restore order and cope after the crisis has settled. They insist that modern research in crisis communication has developed in two directions, encompassing theoretical models and focusing on the role of issues management (Falkheimer and Heide 2006).

An and Cheng (2007) identified research trends in crisis communication through a qualitative approach that reviews public relations articles published in two main journals, the Journal of Public Relations Research and Public Relations Review, between 1975 and 2006. They examined various aspects of the potential changes in crisis research, including research subject or topics, theoretical framework, and methodology in crisis communication research (An and Cheng 2007). Their findings show that research in crisis communication research is on the rise. Just over half of the articles studied (58.1 percent) were published between 2001 and 2006. Research involving evaluation of crisis and examination of the effect of public relations strategies is predominant (65.5 percent), and studies of nonspecific crisis situations (25.7 percent) were quite frequently conducted (An and Cheng 2007). 
Avery et al. (2010) investigated the trend of crisis communication research from a quantitative perspective. Their research investigated longitudinal trends of crisis communication theory in public relations research and its contextual applications between 1991 and 2009. Their study also focused on two primary streams of research, the theory of image restoration discourse (Benoit 1995, 1997) and the situational crisis communication theory (SCCT) (Coombs 2007). These two streams accounted for the majority of articles published on crisis management. Their findings showed that the research about evaluation of crisis case (48.6 percent), examination of the effect of strategies (14.9 percent), and review of definitions, functions, and role of crisis ( 8.1 percent) has been studied more widely than other subjects. Although the field of crisis communication research has indeed proliferated in the past three decades, there was no research focused on ethics as the main topic (Avery et al. 2010). Thus, academic research in the field of crisis communication ethics is less developed (Seeger 2006; Wright $\underline{2006)}$.

While specific theories or models of ethics in crisis communication do not exist, Benoit (1997) and Coombs (2007) have addressed ethical issues in their theories. Benoit's (1997) theory of image restoration discourse is related to message options during crises, including what a corporation can say when faced with a crisis. This theory offers five broad categories of image repair strategies to respond to threats: denial, evasion of responsibility, reduction of event offensiveness, corrective action, and mortification. Some image repair strategies essentially involve ethics in terms of a philosophy that stresses what is right, fair, just, and moral; "denial" is based on honesty; "mortification" involves apologizing for an act, and "corrective action" is used to solve and prevent problems (Benoit 1997). Coombs' SCCT is a framework that allows crisis managers to benefit from understanding how crisis communication can be used to protect reputational assets during a crisis (Coombs 2007). To develop SCCT, Coombs (2007) stressed that the protection of stakeholders from harm is the first priority in any crisis, not the protection of the organization's reputation. He argued that SCCT provides guidance for crisis managers, who have ethical responsibilities when drafting a crisis response. In other words, even though its goal is to maximize the reputational protection afforded by post-crisis communication, SCCT begins with ethical responsibilities (Coombs 2007).

Seeger and UImer (2001) also attempted to fill the gap between the dearth of academic attention to ethics in public relations and ethics as critical issue in practices. They proved that highly ethical crisis communication is effective in rejuvenating affected companies. The study of two crisis cases, the 1995 fire of Malden Mills in Massachusetts and the 1998 fire of Cole Hardwoods in Indiana, shows that immediate response is very important and effective in crisis communication because it reduces the uncertainty of the crisis and its potential harm to stakeholders. Both companies announced their plan for victims and rebuilding almost as soon as the fires were out. Seeger and Ulmer (2001) concluded that responding in very immediate ways played a positive role in ethical crisis communication.

\section{Ethics in Crisis Communication Practices}

Ethics is regarded as the most important element in public relations practice (Gower 2006; PRSA Code of Ethics 2011). Successful public relations hinges on the ethics of its practitioners. The professional public relations associations, including Public Relations Society of America (PRSA) and the International Public Relations Association, created and have continued to maintain a code of ethics to help public relations practitioners navigate ethics principles and applications. In fact, codes of ethics have helped to improve the public's perception of public relations, as a practice and profession. This element of 
professionalism makes unethical behavior less likely (Fisher 2005; Ki et al. 2012; PRSA Code of Ethics 2011). Through examination of codes of ethics in 31 Korean public relations firms, Ki et al. (2012) revealed that practitioners working in firms with ethical parameters were significantly more likely to engage in ethical practices. Seeger's (2006) best practices in crisis communication are strikingly consistent with the ethical guidance offered in the PRSA's code of ethics, which reinforce the importance of ethics in crisis communication (e.g., understanding the audience, honesty, candor, and openness).

Practical cases have also demonstrated the importance of ethics in crisis communication (Gower 2006; McHale et al. 2007; Seeger and Ulmer 2001; Wright 2006). Corporate public relations practices during financial scandals demonstrated the importance of ethical responses to crisis (Gower 2006). Enron and WorldCom faced similar crises when they failed to be honest and ethical in their dealings with the public (Wright 2006). Each company's crisis communication affected its reputation in quite different ways. While Enron's reputation was damaged because of failure to be perceived as transparent, WorldCom received more favorable media coverage because it attempted to be transparent during a crisis. These two cases show the importance of ethical principles, being truthful and transparent, for crisis communication (Gower 2006).

Nike's sweatshop labor crisis also demonstrated the importance of ethics, especially truthfulness, in crisis communication (McHale et al. 2007). In 1996, Nike was the target of numerous mass media attacks alleging abuse of young female workers in plants in Asian countries such as Indonesia, Vietnam, and China (DeTienne and Lewis 2005; McHale et al. 2007). To defend its practices and public reputation during this crisis, Nike responded to allegations in ethical ways, employing truthfulness and transparency, disclosing their corporate social responsibility statements, including a fair employee treatment and a labor report, and commissioning external investigations for the company's foreign workers. In responses to the investigations, the company developed its own code of conduct. Eventually, Nike's ethical crisis communication overcame the crisis brought on by activists and news media who initiated negative publicity (McHale et al. 2007).

More recently, Piotrowski and Guyette (2010) examined ethics in the case of Toyota Motor Corporation's recall crisis in 2009. The crisis was initiated by an allegation that improper installation of an all-weather floor mat led to the sticking of the vehicle's accelerator, which could cause a fatal accident. They found that the company's crisis as criticized by the media, national businesses, and the American public was not attributable to the vehicle's accelerator problem itself. The negative reputation arose from Toyota's resultant unethical crisis communication. The veracity of public statements from Toyota was not publicly trusted, and the public felt to some degree that the company's decision making during the crisis period had been unethical. Moreover, there was little faith in Toyota's transparency during the crisis. Piotrowski and Guyette $(\underline{2010})$ concluded that the American public was largely disappointed in Toyota's ethics during the recall crisis, and such disappointment was likely to not only decrease the company's auto sales but also increase competitors' market share in 2010. They suggested that Toyota's leadership could protect reputational aspects through ethical strategies (Piotrowski and Guyette 2010). 
Crisis communication literature and practice offer common variables-what, how, and when-as essential elements for effective crisis communication. To organize and synthesize the various management insights, Coombs $(\underline{1999}, \underline{2010})$ divided the crisis management process into three stages: pre-crisis, crisis event, and post-crisis. He considered this three-staged approach to be a comprehensive model capable of developing "random" insights into the crisis management process and to articulate what and how actions must be done in every stage. His study implies that every stage in a crisis requires a different approach to crisis communication. For example, in the pre-crisis stage, crisis communication should focus on "what sources to scan, how to collect information, and how to evaluate information for its crisis potential" in order to locate and reduce risk (Coombs 1999, p. 22). The goal of crisis communication is "for use in the process of evaluating crisis management performance in post-crisis stage" (Coombs $\underline{1999}$, p. 146).

Benoit (1997) suggests that a company facing crisis must tailor crisis messages for every different audience. According to Benoit (1997), "the most important audience is appeased first, and then devotes time and effort to the other audiences as possible. This may be done with different messages delivered to different groups" (p. 183). Reynolds and Seeger (2005) point out that communicating timely information to the public is a core function of crisis communication. When a threat erupts into a crisis, different communication exigencies and various audiences emerge. Timely communication with various groups, for instance, victims, potential victims, and close family members, may help mitigate or contain harm. Other researchers stressed the "when" variable by highlighting the importance of such timely communication (González-Herrero and Pratt 1996; Huang 2008; Sillince 2002; Strong et al. 2001; Wei et al. 2010).

Additional case studies related to effective crisis communication have examined the "what," "how," and "when" variables in detail. Tompkins and Anderson (1971) examined the role of communication in the Kent State University crisis, and Cushing's case study (Cushing 1994) of the role that communication plays in airline disasters demonstrated that "the crisis was at least facilitated by organizational communication deficiencies, including two-way communication" (Seeger et al. 1998, p. 240). These two studies stress the importance of two-way communication to prevent a crisis, as well as deal with a crisis in terms of the "how" variable. Other case studies show the "what" that was done in effective crisis communication. Through analysis of Exxon's crisis communication after its Valdez oil spill incident, Small (1991) established that a candid, prompt, honest and complete response in a crisis may also bolster an organization's reputation and integrity in the long run. Seeger and Ulmer (2001) supported Small's (1991) study by demonstrating through two fire crisis cases that prompt response can reduce the uncertainty of the crisis and its potential harm to stakeholders. McHale et al. (2007) also upheld Small's (1991) findings in terms of candidness, honesty, and completeness of response. They further argued that Nike was able to overcome its sweatshop labor crisis through the use of truthful crisis communication (McHale et al. 2007). 
Toward an Ethical Model of Effective Crisis Communication: The TTR Test

Similar to Seeger and UImer's efforts (Seeger and Ulmer 2001) to relieve public relations academics' thirst for an ethical theory or model, this study's goal is also to set forth a new ethical model based on a set of principles for effective crisis communication. We have seen how the aforementioned three common variables, "what," "how," and "when," have led to effective crisis communication. Based on these three variables, a three-part model, the TTR Test, is hereby proposed. The TTR model consists of the three principles: Transparency (what), Two-way symmetrical communication (how), and Right time (when). The TTR Test defines the moral boundaries of crisis communication and serves as a set of action-guiding principles directed toward both moral consequences and effectiveness in dealing with a crisis.

I first show how these three principles can be drawn individually from crisis communication studies and cases, and then discuss them together as a new model by applying them to a current crisis case, the BP oil spill crisis. The TTR Test is strictly limited to crisis communication and altogether avoids risk communication.

Transparency (What)

The first principle of the TTR Test is transparency. Transparency is a measure of the degree to which organizational actions and decisions are ascertainable and understandable by a party interested in those actions or decisions (Gower 2006). It involves "the willingness and responsibility to try to give a meaningful and accurate account of oneself, or of circumstances in which one is involved" (Cotterrell 1999 , p. 419). Nonetheless, the concept of transparency is not limited to just availability of information but involved with active participation in acquiring, distributing, and creating knowledge (Cotterrell 1999). As there is always new information to know or disclose as well as another side to every story to tell, transparency is "an unending process" (Cotterrell 1999; Gower 2006, p. 96).

However, transparency in the TTR Test is a more specific standard value organizations must show during a crisis than literal transparency in the ethics literature because such disclosure of information should be needed for responsible decision making (PRSA Code of Ethics 2011). In order to be transparent, public relations practitioners must acknowledge and respect informational needs and interests of those with whom they communicate, consider the harms that may result from communication, counsel clients and employers to "tell the truth," and balance constituent interests with organizational interests (Fitzpatrick 2006, p. 12; Place 2010). In this sense, transparency should be guided by the relationship between the organization and its various stakeholders, and how much information and what information to share will depend on whether the information significantly affects stakeholders (Gower 2006).

Transparency must be combined with trust and truthfulness. In public relations, trust can be operationalized as an organization "doing what it says it will do" (Ledingham 2003, p. 185) Specifically, trust is the belief that an organization will do its utmost to meet stakeholder's expectations of the organization, in particular, to reduce stakeholders and victim's uncertainty and stress in crisis situation (Seeger and Ulmer 2001). To maintain trust and to ensure that a stakeholder's expectations can be 
met, an organization must consider what stakeholders think about the organization. That is, the organization in the times of crisis should be truthful about its circumstances (Fitzpatrick 2006; Gower 2006). As the recent cases including Enron, WorldCom, Nike, and Toyota's crises showed, trust and truthfulness are essential for crisis communication. While Enron and Toyota did not meet stakeholders' expectations and were not publicly trusted, Nike and WorldCom could maintain trust through their truthful communication (Gower 2006; McHale et al. 2007; Piotrowski and Guyette 2010).

Further, the concept of trustworthy transparency embraces being honest, candid, and factually accurate from an ethical standpoint (Cotterrell 1999; Gower 2006; PR Coalition 2003). Transparency is an organization's willingness based on responsible decision making to disclose information of its business, social, and political activities, leading to responsible openness of information that "stakeholders can see what the organization is doing and understand the reasoning behind its actions" (Gower 2006, p. 95). In order to be transparent, public relations practitioners must acknowledge and respect informational needs and interests of those with whom they communicate, consider the harms that may result from communication, counsel clients and employers to "tell the truth," and balance constituent interests with organizational interests (Fitzpatrick 2006, p. 12; Place 2010). Transparency in the TTR Test encompasses trust, truthfulness, candor, honesty, and openness.

\section{Two-Way Symmetrical Communication (How)}

Two-way symmetrical communication has provided the ethical base for public relations (Bowen $\underline{2004}$, 2005; Fitzpatrick and Gauthier 2001). As two-way symmetrical communication fosters understanding among all parties involved, it is considered as the ideal goal for which public practitioners must strive (Bowen 2004). In practical models and theories of public relations ethics, use of two-way symmetrical crisis communication strengthens the conceptual base of the TTR Test because it is based on a way of satisfying a moral duty to engage in dialog (Bowen 2005; Grunig and Grunig 1996). Furthermore, twoway symmetrical communication plays a pivotal role as one of the principles of responsible advocacy in public relations (Fitzpatrick and Gauthier 2001).

Two-way symmetrical communication is basically assumed to include "telling the truth," "interpreting the client and public to one another," and "management understanding the viewpoints of employees and neighbors as well as employees and neighbors understanding the viewpoints of management" (Grunig and Hunt 1984, p. 42). Its goal is to foster understanding and communication rather than to persuade the public and other stakeholders, and therefore, "exchange information based on dialogue," as well as to create "balance between the organization and public" (Grunig and Grunig 1992, p. 289). Two-way symmetrical communication forms the basis of excellent public relations practice. According to Grunig (1992), "excellent organizations 'stay close' to their customers, employees, and other strategic constituencies" (p. 16).

In short, two-way symmetrical communication is characterized by a willingness of an organization to listen and respond to its key stakeholders' concerns, interests, and actions; that is, using two-way symmetrical communication can satisfy the organization's moral duty to engage in dialog (Bowen 2005). Moreover, symmetry is an inherently ethical form of communication (Grunig 1992, 2001; Grunig and White 1992; Huang 2004; Roper 2005). Two-way symmetrical communication can be achieved through ethical responses based on truth-telling and an understanding of all viewpoints during a crisis, 
which logically implies transparency. Therefore, two-way symmetrical communication in the TTR Test refers to a basic concept: it focuses on "an ethical response to a crisis" (Gower 2006, p. 99).

\section{Right Time (When)}

The old adage representing key principles of crisis communication, "tell it all, tell it fast," supports the notion that "when information gets out quickly, rumors are stopped" (Seitel 2007, p. 408). It seems as if promptness or immediacy is a general rule in public relations practice. In1986, Johnson and Johnson Company was able to quickly terminate a crisis related to allegations of poisoned Tylenol, limit the damage, and restore credibility by providing the public with prompt response (Seitel 2007). Also, the 1995 fire of Malden Mills in Massachusetts and the 1998 fire of Cole Hardwoods in Indiana demonstrated that immediate response is a very important aspect of effective, ethical crisis response, as it reduces stakeholders and victim's uncertainty and stress (Seeger and Ulmer 2001). Most research and case studies to date have focused on "the initial response to a crisis" during the post-crisis phase. Unfortunately, there are currently no studies related to crisis communication that cover every crisis stage. The focus tends to be aimed at promptness or immediacy as the best way to conduct crisis communication, which makes it easy to overlook follow-up crisis communication with stakeholders (Coombs 1999).

Promptness or immediacy needs to be considered with more care when applying it to the life cycle of crisis. An immediate or prompt response is obviously important, especially when it comes to post-crisis communication; however, crisis communication is essential in every crisis stage. Ethical crisis communication should continue throughout the life cycle of a crisis, which includes all three stages: pre, during, and post (Coombs 1999, 2010; González-Herrero and Pratt 1996). Timeliness of communication is one of the factors critical to satisfaction across stakeholder groups (Strong et al. 2001), and the more unpredictable the state of an event or the external environment, the more critical a timely response becomes (Sillince 2002).

Reynolds and Seeger (2005) also urge timely communication, not just immediate release of information to the public, given emerging difference in communication exigencies and audiences in every crisis stage. Furthermore, the finding that the form of the crisis response, including timely, consistent, and active response, is more powerful than crisis communication strategies (denial, diversion, excuse, justification, and concession) to predict trust and relational commitment highlights the importance of timely communication (Huang 2008). Above all, the determination of "right time" to circulate information is crucial for its effective transmission of messages. Crisis information should reach, in a timely fashion, every person who is at risk and wants to be informed (Wei et al. 2010). Consequently, "right time" in the TTR Test refers to communication timing throughout the life cycle of the crisis and timely response to a crisis.

\section{Practical Implications: Analysis of a Crisis Case (the 2010 BP Oil Spill) Based on TTR Test}

To help public relations practitioners use the TTR Test in the "real world," I will apply the TTR Test to the BP oil spill in 2010, to assess BP's ethical communication.

On April 20, 2010, an explosion occurred on the Deepwater Horizon, a drilling rig working on the Macondo exploration well for the oil company BP. The explosion occurred one mile below the surface 
of the water in the Gulf of Mexico, leading to the largest accidental oil spill in history (Deepwater Horizon Accident 2011). Nearly 5 months after it blew out of control, BP and government scientists conducted tests that confirmed the effectiveness of the "static kill." After pumping heavy drilling mud into the well, the federal government finally declared the well dead in September. By November 2010, an emergency program had ended and the settlement phase began (Times Topic 2011). As of December 31, 2011, BP had spent \$14 billion in cleanup and damage compensation costs (Deepwater Horizon Accident 2012). Many experts argue that the crisis communication strategies of BP and former chief executive officer (CEO) Hayward were not successfully conducted (Daniels 2011; Kuzmeski 2010; Roach 2010; Sellnow 2010; Spaeth 2010).

The TTR Test also reveals that BP's crisis communication was unsuccessful based on ethical standards. The company's crisis communication was unethical because their communication did not meet any of the TTR Test standards at the outset the public did not trust BP's crisis communication. Lack of transparency drew close media scrutiny and suspicion (Kuzmeski 2010). It was revealed during several stages of the event that BP was not being completely truthful about the spill. To compound the problem, the company refused to allow the media to get close to the site (Kuzmeski 2010).

On May 14, the beginning stage of the oil spill event, former CEO Tony Hayward said, essentially, that the Gulf of Mexico is a big ocean and claimed that the amount of oil pouring into it was tiny and insignificant (Roach 2010). On top of that, he and BP often changed of the amount of oil spilled and seemed reluctant to provide live video feed of the ruptured pipe-even though they had a higher quality video feed much earlier than previously revealed (Daniels 2011; Kuzmeski 2010; Spaeth 2010). Failure to be fully transparent-failure to disclose what is known and done by the company-resulted in finger pointing and blame. Criticism of BP officials' ethics increased as illustrated by comments from Congress: "time after time, it appears BP made decisions that increased the risk of a blowout to save the company time or expense" (Kuzmeski 2010; Verschoor 2010, p. 14).

Such BP leadership's ambiguous communication to the public and the media did not build confidence but made its communication worse (i.e., not being transparent). The ambiguous public communication involving underestimating the volume of the spill and overestimating the capability of the company to plug the well resulted in an image of incompetence (Veil et al. 2013). Although BP should have provided information that was accurate and factually correct, they failed to communicate with stakeholders honestly, openly, and truthfully (Cotterrell 1999; Gower 2006). In fact, BP utilized public relations tools to provide accurate and factual information through press release issued almost daily to give updates on cleanup and recovery efforts and to progress on stopping the leaks as well as numerous videos on their web sites and social media (e.g., Flickr, Twitter, YouTube) (Muralidharan et al. 2011; Veil et al. 2013). However, their efforts were disingenuous, not sincere, because of ambiguous communication.

Also, BP should have been engaged in crisis communication before they had adequately prepared and practiced. When asked about preparing for a worst case scenario, they answered that the spill was "a completely unanticipated event" (Roach 2010, p. 19).

Eventually, BP's crisis communication was handed over to external organizations. On June 1, Thad Allen, the government's national incident commander, held a daily press briefing without BP, and in July, the White House replaced BP's web site (Daniels 2011). However, by not being fully transparent 
about BP at the initial stage, the U.S. government also missed an opportunity to fully inform the public (Kuzmeski 2010).

In addition, BP's delay in responding to the crisis on the social media can be another evidence of its communication being not at the right time. The explosion on Deepwater Horizon occurred on April 20, 2010, but BP's first tweet and first Flickr photo were on April 27 and the first YouTube video was uploaded on May 27 (Muralidharan et al. 2011). In other words, BP started to use social media only after realizing that the oil spill crisis had already lead to negative reputation from the failure to satisfy stakeholders through a timely response (Muralidharan et al. 2011).

Such delayed response indicates that BP's crisis communication did not satisfy the moral duty to engage in dialog (i.e., the failure of two-way symmetrical communication), resulting in the publics' negative responses on social media (Bowen 2005; Muralidharan et al. 2011). Although BP disseminated information on their corrective actions such as compensation and mortification, its communication efforts did neither alleviate the angry publics nor materially affect general public opinion (Muralidharan et al. 2011). Further, BP's vague response to the public and news media means that BP also failed to engage in two-way symmetrical communication, which is the next component of the TTR Test. This was demonstrated by BP's poor web site operation during a crisis. BP incorporated on its web page a wide range of visuals, including videos, slideshows, diagrams, and live video feeds of the oil flowing into the Gulf. The Deepwater Horizon web site generated more than 150 million page views, sometimes sustaining an average of more than 3 million impressions per day. However, information posted on BP's web site was not trusted by the public because it was operated based on a one-way system. BP showed only their own live video feeds and did not allow people to post pictures of the beaches (Daniels 2011).

Other web sites that employed two-way symmetrical communication were more reliable. For example, Florida Live, a site launched by the nonprofit organization Visit Florida, invited residents to post pictures of beaches so that viewers could see them in real time (Daniels 2011). As of February 2011, almost 6 months after the well was completely capped, BP's web site did not communicate the latest on cleanup efforts (Casey 2011). Thus, BP's web site communication did not meet Grunig and Hunt's (1984) direction and purpose for two-way communication. The web site's role was not sufficient to exchange information that could create a balance between the company and the public. Although BP hired "social media expertise," the company's communication in social media failed to listen and respond to the concerns and interests of its key stakeholders (Daniels 2011, p. 43; Grunig and Grunig 1992; Roper 2005). Further, the company failed to engage proactively in social media. When the crisis hit, conversations were already taking place on Twitter, Facebook, and other social networking sites (Schock 2010). The fact two-way symmetrical communication was not used makes BP's crisis communication unethical.

Above all, crisis communication related to the oil spill was not implemented at the right time; that is, BP did not communicate timely information to the public. During the early days of the spill, there was a lot of finger pointing between the companies involved in the spill. No one wanted to say "this is our fault" (Kuzmeski 2010, p. 38). At the initial stage of the spill, BP did not indicate its responsibility for the explosion happening but attempt to shift blame for the explosion that caused the oil spill to another company, Transocean (Harlow et al. 2011). From April 11 through 28, the company issued six press release "to include some references to BP working with Transocean" and "to imply that BP and 
Transocean were somewhat equally sharing the burden of response to the explosion" (Harlow et al. 2011, p. 82). The result was a situation in which crisis communication could not be implemented at the right time. Even though the company publicly accepted responsibility and its executives certainly expressed remorse for devastating the fragile ecological system and destroying the livelihood of gulf coast residents, it was difficult for the publics to accept the responsibility (Harlow et al. 2011; Veil et al. $\underline{2013}$ ). In other words, the initial response to the crisis was not made with promptness or immediacy. BP's crisis communication did not play a timely role in providing information to reduce the public's harm or uncertainty (Roach 2010; Spaeth 2010).

Within less than a month, the different estimates by BP varied wildly regarding the amount of oil leaking daily into the Gulf of Mexico (1,000 barrels, 5,000 barrels, and 60,000 barrels), which resulted in public criticism (Spaeth 2010). Even though a prompt response was required given the unpredictable nature of the event, BP responded to its stakeholders at the wrong time (Sillince 2002). Furthermore, follow-up communication was also insufficient. BP's crisis communication did not continue in a timely manner throughout the life cycle of crisis. BP and the U.S. government failed to release steady updates regarding their efforts to stop the spill and completely ignored communication regarding implementation of a recovery process (Kuzmeski 2010). The information BP disseminated was offered at the wrong time, as the communication could not reach every stakeholder at risk who wanted to be informed (Wei et al. 2010). As BP's timeliness of communication could not satisfy interests of any stakeholders, including the public and media, their crisis communication strategies could not work (Huang 2008; Strong et al. 2001).

\section{Conclusion}

Although many public relations practices have highlighted the importance of ethics in crisis communication, research about public relations ethics has been paid relatively little attention (Gower 2006; Seeger and Ulmer 2001). Further, to date, there is no any ethical model or theory in the field of crisis communication. The goal of this article was to develop and demonstrate a new ethical model for crisis communication. In order to investigate how the TTR Test can be applied to the real world, oil spill crisis communication was employed. It turned out that BP's crisis communication was unethical when it comes to the TTR Test.

This study, however, has its limitations with respect to applicability and unexhausted ethics standards. The TTR Test offers general standards rather than a specific framework. Each principle (transparency, two-way symmetrical communication, and right time) does not yet consist of a list of questions or scales; that is, the concept of each principle may be vague. For this reason, the application of the test to cases might be challenged by other scholars. Further, this study applied the TTR Test to just one form of crisis - an oil spill. To develop and advance the TTR Test, it must be applied to various crises, such as natural disasters, international events, and a variety of other harm-inducing occurrences, including rumors, malevolence, and misdeeds (Coombs 1999; Seeger 2006). In addition, there are many other ethical values not included in TTR Test. According to the PRSA Code of Ethics, "responsible advocacy" is regarded as one of the core values of public relations, but the TTR Test does not contain or address this value (Fitzpatrick and Bronstein 2006; PRSA Code of Ethics 2011). Toward an ethical model of effective crisis communication, future study should not only provide a more elaborated model based on exhaustive ethics standards and specific frameworks, but also show how the test can be applied to various crises. 
Nonetheless, this study is meaningful because the TTR Test is a new ethical model for effective crisis communication drawn from three common variables from crisis communication literature and practices (what, how, and when). The TTR Test has the potential to be a useful tool for simultaneously understanding effectiveness and ethics in public relations practice by helping public relations professionals to develop solutions for unethical practices as well as to establish effective crisis communication strategy.

\section{References}

An, S. K., and Cheng, I. H. 2007. "Crisis communication research in public relations literature in 19752006," Paper presented at the annual meeting of National Communication Association, Chicago, IL.

Avery, J. E., Lariscy, R. W., Kim, S., and Hocke, T. 2010. “A quantitative review of crisis communication research in public relations from 1991 to 2009," Public Relations Review 36: 190-192.

Barton, L. 1993. Crisis in Organizations: Managing and Communicating in the Heat of Chaos. Cincinnati, $\mathrm{OH}$ : College Divisions South-Western.

Benoit, W. L. 1995. Accounts, excuses, and apologies: A theory of image restoration strategies. Albany, NY: State University of New York Press.

Benoit, W. L. 1997. "Image repair discourse and crisis communication," Public Relations Review 23(2): 177-186.

Bowen, S. A. 2004. "Expansion of ethics as the tenth generic principle of public relations excellence: A Kantian theory and model for managing ethical issues," Journal of Public Relations Research 16(1): 65-92.

Bowen, S. A. 2005. "A practical model for ethical decision making in issues management and public relations," Journal of Public Relations Research 17(3): 191-216.

Casey, B. 2011. "First impressions will be vital for BP's new communications director," PRWeek (U.S.) 14(2): 24.

Coombs, W. T. 1999. Ongoing Crisis Communication: Planning, Managing, and Responding. Thousand Oaks, CA: Sage Publications.

Coombs, W. T. 2007. "Protecting organization reputation during a crisis: The development and application of situation crisis communication theory," Corporate Reputation Review 10(3): 163176.

Coombs, W. T. 2010. "Parameters for crisis communication," in W. T. Coombs and S. J. Holladay, eds., The Handbook of Crisis Communication. Malden, MA: Willey-Blackwell, pp. 17-53. 
Cotterrell, R. 1999. "Transparency, mass media, ideology and community," Cultural Values 3(4): 414426.

Cushing, S. 1994. Fatal Words: Communication Clashes and Aircraft Crashes. Chicago, IL: University of Chicago Press.

Daniels, C. 2011. “BP: A year later,” PRWeek (U.S.) 14(2): 40-43.

Deepwater Horizon Accident. 2011. "Gulf of Mexico restoration,” $\underline{\mathrm{bp} . c o m}$, http://www.bp.com/sectiongenericarticle800.do?categoryld=9036575\&contentld=7067541, accessed April 24, 2011.

Deepwater Horizon accident. 2012. "Gulf of Mexico restoration," bp.com, http://www.bp.com/sectiongenericarticle800.do?categoryld=9036575\&contentld=7067541, accessed July 7, 2012.

DeTienne, K. B., and Lewis, L. W. 2005. "The pragmatic and ethical barriers to corporate social responsibility disclosure: The Nike case," Journal of Business Ethics 60: 359-376.

Falkheimer, J., and Heide, M. 2006. "Multicultural crisis communication: Toward a social constructionist perspective," Journal of Contingence and Crisis Management 14(4): 180-189.

Fearn-Banks, K. 1996. Crisis Communications: A Casebook Approach. Mahwah, NJ: Lawrence Erlbaum.

Fearn-Banks, K. 2002. Crisis Communications, 2nd ed. Mahwah, NJ: Lawrence Erlbaum.

Fisher, B. A. 2005. "The ethical foundation of PR: An analysis of public relations firms' codes of ethics," Paper presented at the annual meeting of International Communication Association, New York, NY.

Fitzpatrick, K. 2006. "Baselines for ethical advocacy in the "marketplace of ideas"," in K. R. Fitzpatrick and C. Bronstein, eds., Ethics in Public Relations: Responsible Advocacy. Thousand Oaks, CA: Sage, pp. 1-17.

Fitzpatrick, K., and Bronstein, C. 2006. "Introduction: Toward a definitional framework for responsible advocacy," in K. R. Fitzpatrick and C. Bronstein, eds., Ethics in Public Relations: Responsible Advocacy. Thousand Oaks, CA: Sage, pp. ix-xiv.

Fitzpatrick, K., and Gauthier, C. 2001. "Toward a professional responsibility theory of public relations ethics," Journal of Mass Media Ethics 16(2\&3): 193-212.

González-Herrero, A., and Pratt, C. B. 1996. "An integrated symmetrical model for crisiscommunications management," Journal of Public Relations Research 8(2): 79-105.

Gower, K. K. 2006. "Truth and transparency," in K. R. Fitzpatrick and C. Bronstein, eds., Ethics in Public Relations: Responsible Advocacy. Thousand Oaks, CA: Sage, pp. 89-105. 
Grunig, J. E. 1992. "Communication, public relations, and effective organizations: An overview of the book," in J. E. Grunig, ed., Excellence in Public Relations and Communication Management. Hillsdale, NJ: Erlbaum Associates, pp. 1-28.

Grunig, J. E. 2001. "Two-way symmetrical public relations: Past, present, and future," in R. L. Health, ed., Handbook of public relations. Thousand Oaks, CA: Sage, pp. 11-30.

Grunig, J. E., and Grunig, L. A. 1992. “Models of public relations and communication,” in J. E. Grunig, ed., Excellence in Public Relations and Communication Management. Hillsdale, NJ: Erlbaum Associates, pp. 285-326.

Grunig, J. E., and Grunig, L. A. 1996. "Implication of symmetry for a theory of ethics and social responsibility in public relations," Paper presented at the meeting of the International Communication Association, Chicago, IL.

Grunig, J. E., and Hunt, T. 1984. Managing Public Relations. New York, NY: Holt, Rinehart \& Winston.

Grunig, J. E., and White, J. 1992. "The effect of worldviews on public relations theory and practice," in J. E. Grunig, ed., Excellence in Public Relations and Communication Management. Hillsdale, NJ: Erlbaum Associates, pp. 31-64.

Harlow, W. F., Brantley, B. C., and Harlow, R. M. 2011. "BP initial image repair strategies after the Deepwater Horizon spill," Public Relations Review 37: 80-83.

Heath, R. L., and Ryan, M. 1989. "Public relations' role in defining corporate social responsibility," Journal of Mass Media Ethics 4(1): 21-38.

Hon, L. 2006. "Negotiating relationships with activist publics," in K. R. Fitzpatrick and C. Bronstein, eds., Ethics in Public Relations: Responsible Advocacy. Thousand Oaks, CA: Sage, pp. 89-105.

Huang, Y. H. 2004. "Is symmetrical communication ethical or effective?," Journal of Business Ethics 53: 333-352.

Huang, Y. H. 2008. "Trust and relational commitment in corporate crises: The effects of crisis communicative strategy and form of crisis response," Journal of Public Relations Research 20: 297-327.

Kell, J. 2011. "Toyota sales drop 5.5\% in Dec; 2010 sales slide from 2009," The Wall Street Journal.com, January 4, http://online.wsj.com/article/BT-CO-20110104-709115.html, accessed April 162011.

Ki, E. J., Choi, H. L., and Lee, J. H. 2012. "Does ethics statement of a public relations firm make a difference? Yes it does!!," Journal of Business Ethics 105(2): 267-276.

Kuzmeski, M. 2010. “Lessons from the gulf oil spill," ABA Bank Marketing 42(7): 36-40.

Ledingham, J. A. 2003. "Explicating relationship management as a general theory of public relations," Journal of Public Relations Research 15(2): 181-198. 
Liker, J. 2011. "Toyota's recall crisis: What have we learned?," Harvard Business Review.org, February 11, http://blogs.hbr.org/cs/2011/02/toyotas_recall_crisis full_of.html, accessed April 18, 2011.

McHale, J. P., Zompetti, J. P., and Moffitt, M. A. 2007. "A hegemonic model of crisis communication," Journal of Business Communication 44(4): 374-402.

Muralidharan, S., Dillistine, K., and Shin, J.-H. 2011. "The Gulf Coast oil spill: Extending the theory of image restoration discourse to the realm of social media and beyond petroleum," Public Relations Review 37: 226-232.

Palenchar, M. I., and Heath, R. L. 2006. "Responsible advocacy through strategic risk communication," in K. R. Fitzpatrick and C. Bronstein, eds., Ethics in Public Relations: Responsible Advocacy. Thousand Oaks, CA: Sage, pp. 133-153.

Piotrowski, C., and Guyette, R. W. Jr. 2010. "Toyota recall crisis: Public attitudes on leadership and ethics," Organizational Development Journal 28(2): 89-97.

Place, K. 2010. "A qualitative examination of public relations practitioner ethical decision making and the deontological theory of ethical issues management," Journal of Mass Media Ethics 25: 226245.

PR Coalition. (2003). "Restoring trust in business: Models for action," Corporate communication international.org, http://www.corporatecomm.org/pdf/PRCoalitionPaper 9 11Final.pdf, accessed April 21, 2011.

PRSA Code of Ethics. (2011). "Public Relations Society of America (PRSA) Member Code of Ethics," PRSA.org, http://www.prsa.org/aboutprsa/ethics/?utm campaign=PRSASearch\&utm source=PRSAWebsi te\&utm medium=SSearch\&utm term=ethics, accessed April 19, 2011.

Reynolds, B., and Seeger, M. W. 2005. "Crisis and emergency risk communication as an integrative model," Journal of Health Communication 10: 43-55.

Roach, T. J. 2010. “BP's PR lessons,” Rock Products 113(8): 18-20.

Roper, J. 2005. "Symmetrical communication: Excellent public relations or a strategy for hegemony?," Journal of Public Relations Research 17(1): 69-86.

Schock, N. 2010. “Handling a fake Twitter account," Public Relations Strategist 16(3): 8-9.

Seeger, M. W. 2006. "Best practices in crisis communication: An expert panel process," Journal of Applied Communication Research 34(3): 232-244.

Seeger, M. W., and Ulmer, R. R. 2001. "Virtuous responses to organization crisis: Aaron Feuerstein and Milt Cole," Journal of Business Ethics 31: 369-376. 
Seeger, M. W., Sellnow, T. L., and Ulmer, R. R. 1998. "Communication, organization and crisis," in M. E. Roloff, ed., Communication Yearbook 21. Thousand Oaks, CA: Sage, pp. 231-275.

Seitel, F. 2007. The Practice of Public Relations, 10th ed. Upper Saddle River, NJ: Prentice Hall.

Sellnow, T. L. 2010. "BP's crisis communication: Finding redemption through renewal," Communication Currents 5(4): 1-2.

Sillince, J. A. 2002. "A model of the strength and appropriateness of argumentation in organizational contexts," Journal of Management Studies 39: 585-618.

Small, W. 1991. "Exxon Valdez: How to spend billions and still get a black eye," Public Relations Review 17(1): 9-26.

Spaeth, M. 2010. “BP's oil spill,” Leadership Excellence 27(10): 19.

Strong, K. C., Ringer, R. C., and Taylor, S. A. 2001. "The rules of stakeholder satisfaction (timelines, honestly, empathy)," Journal of Business Ethics 32: 219-230.

Times Topic. 2011. "Gulf of Mexico oil spill (2010)," The New York Times, February 2, http://topics.nytimes.com/top/reference/timestopics/subjects/o/oil spills/gulf of mexico 20 10/index.html?scp=1-spot\&sq=gulf\%20oil\%20spill\&st=cse, accessed April 24, 2011.

Tompkins, P. K., and Anderson, E. V. B. 1971. Communication Crisis at Kent State. New York, NY: Gordon \& Breach.

Veil, S. R., Sellnow, T. L., and Wickline, M. C. 2013. "British petroleum: An egregious violation of the ethic of first and second things," Business and Society Review 118(3): 362-381.

Verschoor, C. C. 2010. “BP still hasn't learned ethical lessons," Strategic Finance 92(2): 13-15.

Wei, J., Zhao, D., Yang, F., Du, S., and Marinova, D. 2010. "Timing crisis information release via television," Disasters 34(4): 1013-1030.

Wright, D. K. 2006. "Advocacy across borders," in K. R. Fitzpatrick and C. Bronstein, eds., Ethics in Public Relations: Responsible Advocacy. Thousand Oaks, CA: Sage, pp. 171-190. 